\title{
Enantioselective total synthesis of atpenin A5
}

\author{
Masaki Ohtawa $^{1}$, Satoru Ogihara ${ }^{1}, K$ Kouhei Sugiyama ${ }^{1}$, Kazuro Shiomi ${ }^{2}$, Yoshihiro Harigaya ${ }^{1}$, Tohru Nagamitsu ${ }^{1}$ \\ and Satoshi Ōmura ${ }^{3}$ \\ Enantioselective total synthesis of atpenin A5, a potent mitochondrial complex II (succinate-ubiquinone oxidoreductase) \\ inhibitor, has been achieved by a convergent approach through a coupling reaction between 5 -iodo-2,3,4,6-tetraalkoxypyridine \\ and a side-chain aldehyde. The two key segments were synthesized through ortho-metalation/boronation with $(\mathrm{MeO})_{3} \mathrm{~B} / \mathrm{oxidation}$ \\ with $m C P B A$, ortho-iodination, halogen dance reaction, Sharpless epoxidation and regioselective epoxide-opening reaction. This \\ synthetic study resulted in the revision of the earlier reported ${ }^{1} \mathrm{H}-\mathrm{NMR}$ data of the natural atpenin $\mathrm{A} 5$ and the confirmation of \\ the stereochemical assignment.
}

The Journal of Antibiotics (2009) 62, 289-294; doi:10.1038/ja.2009.29; published online 17 April 2009

Keywords: atpenin A5; complex II inhibitor; enantioselective total synthesis

\section{INTRODUCTION}

Atpenins ${ }^{1,2}$ were first isolated from the fermentation broth of a fungal strain, Penicillium sp. FO-125, as growth inhibitors of both fatty acid synthase-deficient (A-1) and acyl-CoA synthase I-deficient (L-7) mutants of Candida lipolytica and atpenin B were shown to inhibit the ATP-generating system of Raji cells (Figure 1). They inhibited the growth of filamentous fungi. The absolute configuration of atpenin A4 (2) was confirmed by X-ray crystallographic analysis. ${ }^{3}$ The total synthesis of $( \pm)$-atpenin B (1) was reported by Quéguiner and coworkers. ${ }^{4}$ Recently, atpenins were rediscovered as a result of microbial screening for mitochondrial complex II (succinate-ubiquinone oxidoreductase) inhibitors. ${ }^{5}$ Among them, atpenin A5 (3) proved to be much more potent against bovine heart complex II than known complex II inhibitors. Furthermore, the crystal structure analysis of Escherichia coli complex II-atpenin A5 (3) complex has been achieved, and catalytic reduction of quinone was suggested to occur at the atpenin-binding site of E. coli complex II. ${ }^{6}$ As described, atpenins are expected to be useful as biochemical tools in the molecular-biological research of complex II. We report herein the enantioselective total synthesis of atpenin A5 (3) by a convergent strategy through a coupling reaction between 2,3,4,6-tetraalkoxypyridine (4a) and a side-chain aldehyde (5), as shown in Figure 2. The 2,3,4,6-tetraalkoxypyridine (4a) would be constructed from 2-chloro-3-pyridinol (6) through the modified Quéguiner's procedure as follows: (1) directed ortho-lithiation/iodination, (2) halogen dance reaction ${ }^{7}$ and (3) installation of a hydroxy group on the pyridine ring through a one-pot procedure by a sequence of reactions, and halo-lithium exchange/quenching with $(\mathrm{MeO})_{3} \mathrm{~B} /$ oxidation. The side-chain aldehyde $\mathbf{5}$ could be synthesized from a commercially available chiral ester 7 by Sharpless asymmetric epoxidation $^{8}$ and regioselective epoxide opening as key reactions.

\section{RESULTS AND DISCUSSION}

The synthesis of $\mathbf{4 a}$ began with the conversion of the commercially available 2-chloro-3-pyridinol 6 into a known 4-hydroxypyridine 8 (51\%, 3 steps), according to the Quéguiner's atpenin B synthesis ${ }^{4}$ (Scheme 1). In the earlier synthesis, the next key reaction was a directed ortho-lithiation, followed by bromination, in which the use of a diisopropyl carbamate group as a protecting group for the 4-hydroxy group was essential for the directed ortho-lithiation. However, the treatment required to deprotect the diisopropyl carbamate group in the final stage of total synthesis $(5 \mathrm{M}$ solution of $\mathrm{KOH}$ in methanol under reflux) would lead to significant epimerization at the C8 position (in atpenin A5 numbering). Therefore, we looked at other approaches to provide 5-halogenation and protection of the 4-hydroxy group. After various unfruitful trials, the problem was solved by a very simple and mild method, in which 8 was treated with $\mathrm{K}_{2} \mathrm{CO}_{3}$ and $\mathrm{I}_{2}$ in water (for similar reaction conditions, see Kay et al. ${ }^{9}$ ) to afford the desired 4-hydroxy-5-iodopyridine $\mathbf{9}$ in $75 \%$ yield. This modification allowed the use of an easily removable protecting group and led us to the synthesis of an MOM ether 10 (90\% yield). Subsequent halogen dance reaction of $\mathbf{1 0}$ with lithium diisopropylamide smoothly proceeded to afford 6-iodopyridine $\mathbf{1 1}$ in 75\% yield. Treatment of $\mathbf{1 1}$ with $n$-butyl lithium for halo-lithium exchange, boronation with $(\mathrm{MeO})_{3} \mathrm{~B}$ and oxidation with $m$ CPBA (used instead of trifluoroperacetic acid because of its ease in handling) gave 6-hydroxy-5-iodopyridine 13, not 12, in $76 \%$ yield with good reproducibility. The iodopyridinol 13 would be obtained by ortho-iodination of 12 with iodine, which was easily generated in situ by oxidation of the iodide with $m$ CPBA under

\footnotetext{
${ }^{1}$ School of Pharmacy, Kitasato University, Shirokane, Minato-ku, Tokyo, Japan; ${ }^{2}$ Kitasato Institute for Life Sciences and Graduate School of Infection Control Sciences, Kitasato University, Shirokane, Minato-ku, Tokyo, Japan and ${ }^{3}$ Kitasato Institute for Life Sciences, Kitasato University, Shirokane, Minato-ku, Tokyo, Japan

Correspondence: Dr T Nagamitsu, School of Pharmacy, Kitasato University, 5-9-1 Shirokane, Minato-ku, Tokyo 108-8641, Japan.

E-mail: nagamitsut@pharm.kitasato-u.ac.jp or Professor S Ōmura, Kitasato Institute for Life Sciences, Kitasato University, 5-9-1 Shirokane, Minato-ku, Tokyo 108-8641, Japan. E-mail: omura-s@kitasato.or.jp

Received 4 February 2009; revised 11 March 2009; accepted 16 March 2009; published online 17 April 2009
} 


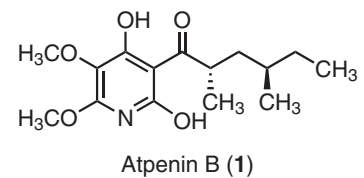<smiles>COc1nc(O)c(C(=O)[C@H](C)CC(C)C(C)Cl)c(O)c1OC</smiles><smiles>COc1nc(O)c(C(=O)[C@H](C)CC(C)C(Cl)CCl)c(O)c1OC</smiles>

Figure 1 Structures of atpenins B (1), A4 (2) and A5 (3).

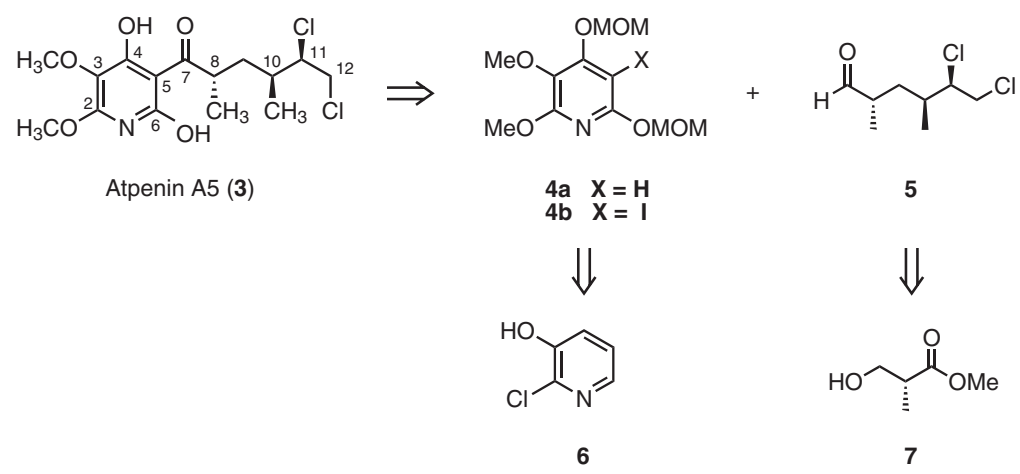

Figure 2 Retrosynthesis of atpenin A5 (3).

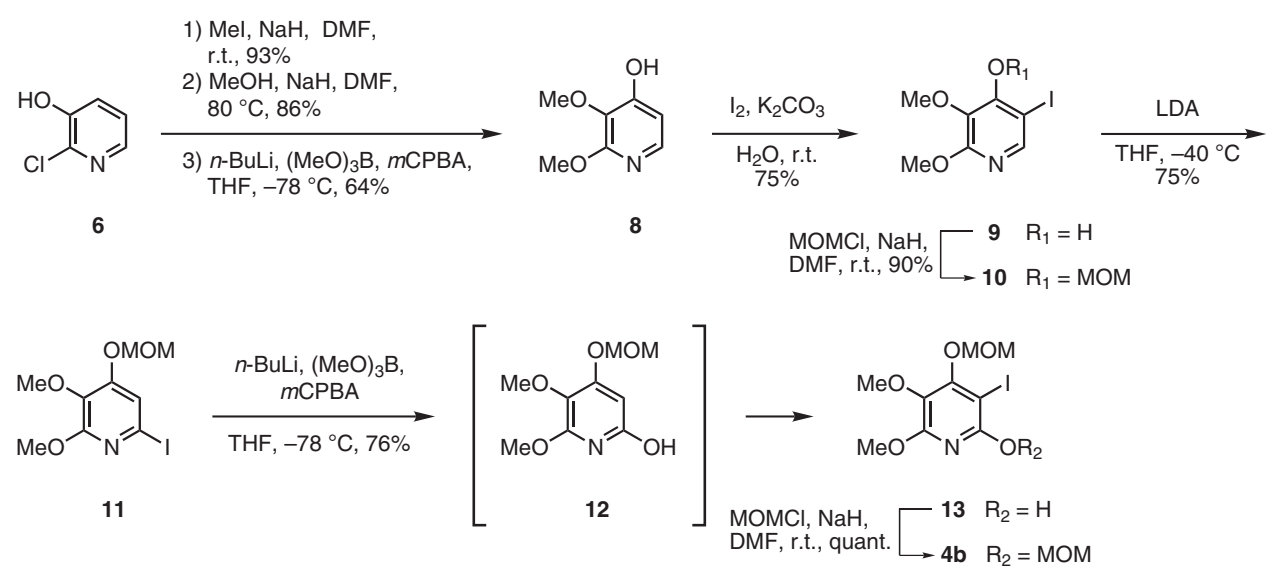

Scheme 1 Synthesis of 5-iodo-2,3,4,6-tetraalkoxypyridine $\mathbf{4 b}$.

basic conditions. The iodopyridinol 13 was protected as an MOM ether to furnish 5-iodo-2,3,4,6-tetraalkoxypyridine $\mathbf{4 b}$ in a quantitative yield, which is the desirable alternative to 2,3,4,6-tetraalkoxypyridine $4 \mathrm{a}$ in terms of the coupling reaction with the side chain 5 .

The stereoselective construction of the other required fragment, aldehyde 5, was carried out as summarized in Scheme 2. A readily available alcohol 14 (Komatsu et al., ${ }^{10}$ enantiomeric excess was determined by ${ }^{19} \mathrm{~F}-\mathrm{NMR}$ spectroscopy after esterification with Mosher's acid.), derived from the commercially available ester 7, was subjected to tosylation, followed by a nucleophilic substitution reaction with potassium cyanide to give nitrile $\mathbf{1 6}$ quantitatively over two steps. The cyano group in $\mathbf{1 6}$ was reduced with DIBAL to afford a known aldehyde 17 in $73 \%$ yield. ${ }^{11}$ Subsequent two-carbon elongation with $\mathrm{Ph}_{3} \mathrm{P}=\mathrm{CHCO}_{2}$ Et provided 18 in $85 \%$ yield. Reduction of the ethyl ester 18 with DIBAL, followed by Sharpless asymmetric epoxidation with (-)-DET, afforded the desired epoxy alcohol 20 as a single diastereomer in $91 \%$ yield over two steps. (The epoxidation of the corresponding allyl alcohol with $m$ CPBA as a simple achiral epoxidizing agent gave a 1:1 diastereomixture of the epoxy alcohol.) Alcohol 20 was protected as a trityl ether and subjected to the regioselective epoxide-opening reaction with $\mathrm{Me}_{2} \mathrm{CuLi}$ and $\mathrm{BF}_{3} \cdot \mathrm{Et}_{2} \mathrm{O}^{12}$ to furnish alcohol 22 as a single diastereomer in $94 \%$ yield over two steps. Birch reduction to remove the trityl group gave diol 23 in $85 \%$ yield. Bischlorination by treatment of diol 23 with NCS and $\mathrm{PPh}_{3}$ followed by deprotection of the TIPS ether with TBAF, gave 24 in $65 \%$ yield over two steps. ${ }^{13}$ Oxidation of alcohol 24 with TEMPO and $\mathrm{PhI}(\mathrm{OAc})_{2}$ afforded the key fragment $\mathbf{5}$ in $81 \%$ yield.

With the required fragments, $\mathbf{4 b}$ and $\mathbf{5}$, in hand, coupling reaction was attempted as the next key step (Scheme 3). Halo-lithium exchange of $\mathbf{4 b}$ with $n$-BuLi, followed by treatment of aldehyde $\mathbf{5}$ gave the desired coupled product $\mathbf{2 5}$ as a diastereomixture in $83 \%$ yield. Oxidation of $\mathbf{2 5}$ with Dess-Martin periodinane provided 26 in $86 \%$ yield. Finally, cleavage of the bis-MOM ether in 26 with TFA afforded atpenin A5 (3) in 93\% yield. However, the ${ }^{1} \mathrm{H}-\mathrm{NMR}$ spectrum of our synthetic atpenin A5 (3) had different chemical shifts from those reported in the literature for the natural product, although the peak patterns were quite similar. As a result, we re-measured the ${ }^{1} \mathrm{H}-\mathrm{NMR}$ spectrum of the natural atpenin A5 (3) and found that the earlier reported data were incorrect. In fact, our synthetic atpenin A5 (3) was completely identical to an authentic sample in all respects. 

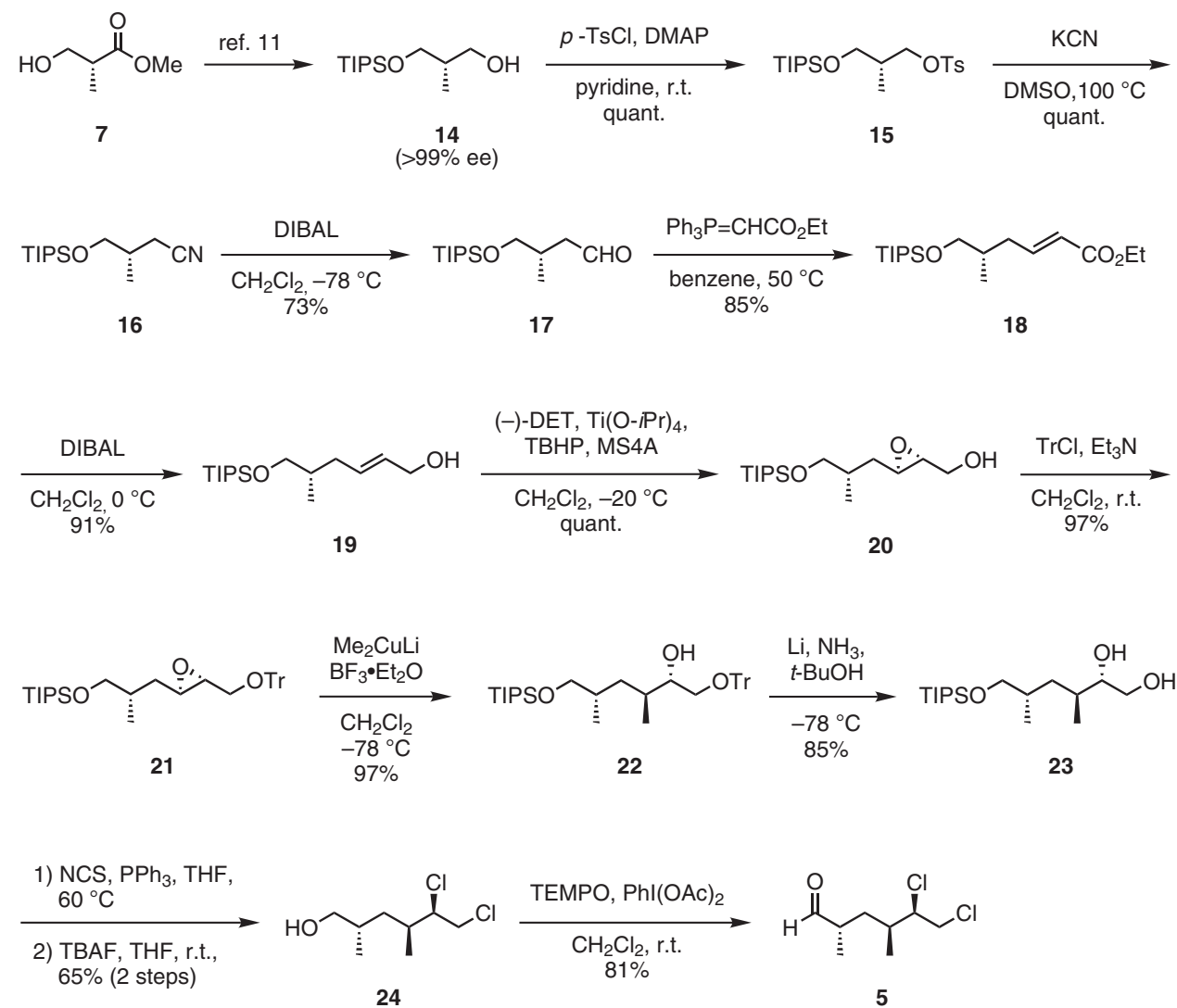

Scheme 2 Synthesis of aldehyde 5.<smiles>COc1nc(OC)c(OC)c(OC)c1OC</smiles>

$4 b$<smiles>COc1nc(OC)c(C(=O)[C@@H](CC(C)C(Cl)CCl)OC)c(OC)c1OC</smiles>

26
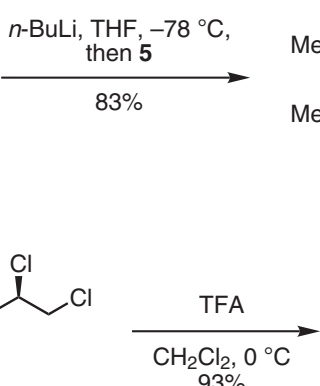

$93 \%$

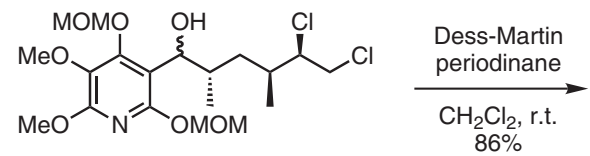

25<smiles>COc1nc(O)c(C(=O)CC(C)C(Cl)CCl)c(O)c1OC</smiles>

Atpenin A5 (3)

Scheme 3 Completion of the total synthesis of atpenin A5 (3).

In summary, the first enantioselective total synthesis of atpenin A5 has been achieved by a convergent approach. The syntheses of the other congeners (A4 and B), and the analogs as well as the biological evaluation of $\mathbf{3}$, are currently in progress in our laboratories.

\section{EXPERIMENTAL SECTION}

\section{General}

Melting points were measured with a Yanagimoto MP apparatus (Yanagimoto, Kyoto, Japan) and remain uncorrected. UV and IR spectra were obtained using an Agilent 8453 spectrophotometer (Agilent Technologies, Waldbornn, Germany) and a Horiba FT-710 spectrophotometer (Horiba, Kyoto, Japan) respectively. ${ }^{1} \mathrm{H}$ - and ${ }^{13} \mathrm{C}-\mathrm{NMR}$ spectra were obtained on JEOL JNM-EX-270 (JEOL, Tokyo, Japan), Mercury-300 (Varian, Palo Alto, CA, USA), UNITY-400 (Varian) and INOVA-600 (Varian) spectrometers, and chemical shifts were reported on the $\delta$ scale from internal TMS. MS spectra were measured with
JEOL JMS-700 (JEOL) and JEOL JMS-AX505HA (JEOL) spectrometers. Optical rotations were recorded on a JASCO DIP-1000 polarimeter (JASCO, Tokyo, Japan). Elemental analyses were performed on a Yanako-MT5 (Yanako, Kyoto, Japan). Commercial reagents were used without further purification unless otherwise indicated. Organic solvents were distilled and dried over molecular sieves ( 3 or $4 \AA$ ). Reactions were carried out in a flame-dried glassware under positive Ar pressure while stirring with a magnetic stirbar unless otherwise indicated. Flash chromatography was carried out on silica gel $60 \mathrm{~N}$ (spherical, neutral, particle size $40-50 \mathrm{~mm}$ ). TLC was performed on $0.25 \mathrm{~mm}$ E Merck silica gel $60 \mathrm{~F} 254$ plates and visualized by UV $(254 \mathrm{~nm})$ and cerium ammonium molybdenate.

\section{5-Iodo-2,3-dimethoxypyridin-4-ol (9)}

A solution of 2,3-dimethoxypyridin-4-ol $8(440 \mathrm{mg}, 2.84 \mathrm{mmol})$ in $\mathrm{H}_{2} \mathrm{O}$ $(6.3 \mathrm{ml})$ was treated with $\mathrm{K}_{2} \mathrm{CO}_{3}(785 \mathrm{mg}, 5.68 \mathrm{mmol})$ and $\mathrm{I}_{2}(742 \mathrm{mg}$, $2.93 \mathrm{mmol})$. The reaction mixture was stirred at room temperature for $1 \mathrm{~h}$, 
quenched with saturated aqueous $\mathrm{NH}_{4} \mathrm{Cl}$ and extracted with $\mathrm{CH}_{2} \mathrm{Cl}_{2}$. The organic layers were combined, dried over $\mathrm{Na}_{2} \mathrm{SO}_{4}$, filtered and concentrated in vacuo. The residue was purified by silica gel flash column chromatography (10:1 hexanes/EtOAc) to afford 9 (598 $\mathrm{mg}, 75 \%)$ as a yellow solid. mp 134$136^{\circ} \mathrm{C}$; IR (KBr) 2998, 2942, 1571, 1473, 1403, 1319, 1261, 1191, 1002, 761, $651 \mathrm{~cm}^{-1}$; ${ }^{1} \mathrm{H}-\mathrm{NMR}\left(270 \mathrm{MHz}, \mathrm{CDCl}_{3}\right) \delta 8.02(\mathrm{~s}, 1 \mathrm{H}), 3.97(\mathrm{~s}, 3 \mathrm{H}), 3.88$ $(\mathrm{s}, 3 \mathrm{H}) ;{ }^{13} \mathrm{C}-\mathrm{NMR}\left(150 \mathrm{MHz}, \mathrm{CDCl}_{3}\right) \delta 157.3,155.0,147.2,130.1,73.0,60.7$, 53.9; HRMS (FAB, $m$-NBA) $[\mathrm{M}+\mathrm{H}]^{+}$calcd for $\mathrm{C}_{7} \mathrm{H}_{9} \mathrm{NO}_{3} \mathrm{I} 281.9627$, found 281.9627.

\section{5-Iodo-2,3-dimethoxy-4-(methoxymethoxy)pyridine (10)}

A solution of $9(58.0 \mathrm{mg}, 206 \mu \mathrm{mol})$ in DMF $(2.0 \mathrm{ml})$ was treated with $\mathrm{NaH}$ $(60 \%, 12.4 \mathrm{mg}, 309 \mu \mathrm{mol})$ and $\mathrm{MOMCl}(24 \mu \mathrm{l}, 309 \mu \mathrm{mol})$. The reaction mixture was stirred at room temperature for $1 \mathrm{~h}$, quenched with $\mathrm{H}_{2} \mathrm{O}$ and extracted with $\mathrm{CH}_{2} \mathrm{Cl}_{2}$. The organic layers were combined, dried over $\mathrm{Na}_{2} \mathrm{SO}_{4}$, filtered and concentrated in vacuo. The residue was purified by silica gel flash column chromatography (20:1 hexanes/EtOAc) to afford $10(60.3 \mathrm{mg}, 90 \%)$ as a yellow solid. mp $57-59^{\circ} \mathrm{C}$; IR (KBr) $3062,2989,2944,2836,1735,1563,1467$, $1400,1211,1164,1105,904,617,586 \mathrm{~cm}^{-1} ;{ }^{1} \mathrm{H}-\mathrm{NMR}\left(270 \mathrm{MHz}, \mathrm{CDCl}_{3}\right) \delta$ $8.10(\mathrm{~s}, 1 \mathrm{H}), 5.36(\mathrm{~s}, 2 \mathrm{H}) 3.95(\mathrm{~s}, 3 \mathrm{H}), 3.81(\mathrm{~s}, 3 \mathrm{H}), 3.60(\mathrm{~s}, 3 \mathrm{H}) ;{ }^{13} \mathrm{C}-\mathrm{NMR}$ $\left(150 \mathrm{MHz}, \mathrm{CDCl}_{3}\right) \delta 159.6,155.2,147.6,135.6,98.7,80.9,60.5,58.1,53.9$; HRMS (FAB, m-NBA) $[\mathrm{M}+\mathrm{H}]^{+}$calcd for $\mathrm{C}_{9} \mathrm{H}_{13} \mathrm{NO}_{4} \mathrm{I}$ 325.9890, found 325.9890 .

\section{6-Iodo-2,3-dimethoxy-4-(methoxymethoxy)pyridine (11)}

To a solution of $i \mathrm{Pr}_{2} \mathrm{NH}(67 \mu \mathrm{l}, 471 \mu \mathrm{mol})$ in THF $(0.4 \mathrm{ml})$ was added dropwise $n$-BuLi ( $1.61 \mathrm{M}$ in hexane, $293 \mu \mathrm{l}, 471 \mu \mathrm{mol})$. After stirring for $30 \mathrm{~min}$ at $0{ }^{\circ} \mathrm{C}$, a solution of $10(51.0 \mathrm{mg}, 157 \mu \mathrm{mol})$ in THF $(0.4 \mathrm{ml})$ was added at $-40{ }^{\circ} \mathrm{C}$, and the resulting mixture was further stirred for $1 \mathrm{~h}$ at $-40^{\circ} \mathrm{C}$. EtOH was added, and the resulting solution was partitioned between EtOAc and $\mathrm{H}_{2} \mathrm{O}$. The aqueous layer was extracted with EtOAc, and the organic layers were combined, dried over $\mathrm{Na}_{2} \mathrm{SO}_{4}$, filtered and concentrated in vacuo. The residue was purified by silica gel flash column chromatography (10:1 hexanes/EtOAc) to afford 11 (38.3 mg, 75\%) as a yellow solid. mp 59-61 ${ }^{\circ} \mathrm{C}$; IR (KBr) 3097, 2944, 1571, $1479,1367,1240,1162,1114,1072,995,912,844,740,441 \mathrm{~cm}^{-1}$; ${ }^{1} \mathrm{H}-\mathrm{NMR}$ $\left(270 \mathrm{MHz}, \mathrm{CDCl}_{3}\right) \delta 7.15(\mathrm{~s}, 1 \mathrm{H}), 5.21(\mathrm{~s}, 2 \mathrm{H}), 3.95(\mathrm{~s}, 3 \mathrm{H}), 3.82(\mathrm{~s}, 3 \mathrm{H}), 3.48$ $(\mathrm{s}, 3 \mathrm{H}) ;{ }^{13} \mathrm{C}-\mathrm{NMR}\left(150 \mathrm{MHz}, \mathrm{CDCl}_{3}\right) \delta 157.8,156.9,132.8,116.5,105.0,94.7$, 60.7, 56.6, 54.4; HRMS (FAB, $m$-NBA) $[\mathrm{M}+\mathrm{H}]^{+}$calcd for $\mathrm{C}_{9} \mathrm{H}_{13} \mathrm{NO}_{4} \mathrm{I}$ 325.9890, found 325.9894 .

\section{3-Iodo-5,6-dimethoxy-4-(methoxymethoxy)pyridin-2-ol (13)}

A solution of $n-\mathrm{BuLi}(1.59 \mathrm{M}$ in hexane, $2.38 \mathrm{ml}, 1.51 \mathrm{mmol})$ in THF $(15 \mathrm{ml})$ was treated with a solution of $\mathbf{1 3}(491 \mathrm{mg}, 1.51 \mathrm{mmol})$ in THF $(15 \mathrm{ml})$ at $-78^{\circ} \mathrm{C}$. Trimethylborate $(507 \mu \mathrm{l}, 4.53 \mathrm{mmol})$ was added and the mixture was stirred for $5 \mathrm{~min}$ at $-78{ }^{\circ} \mathrm{C}$. In addition, $m$ CPBA $(60 \%, 1.74 \mathrm{~g}, 6.04 \mathrm{mmol})$ was added and the mixture was stirred for $30 \mathrm{~min}$. Saturated aqueous $\mathrm{Na}_{2} \mathrm{~S}_{2} \mathrm{O}_{3}$ was added, and the resulting solution was partitioned between EtOAc and $\mathrm{H}_{2} \mathrm{O}$. The aqueous layer was extracted with EtOAc, and the organic layers were combined, dried over $\mathrm{Na}_{2} \mathrm{SO}_{4}$, filtered and concentrated in vacuo. The residue was purified by silica gel flash column chromatography (20:1 hexanes/EtOAc) to afford 13 (393 mg, 76\%) as a white solid. $\mathrm{mp} 119-121^{\circ} \mathrm{C}$; IR (KBr) 3116, 2987, 2832, $2547,1600,1467,1386,1112,894,819,767 \mathrm{~cm}^{-1}$; ${ }^{1} \mathrm{H}-\mathrm{NMR}\left(270 \mathrm{MHz}, \mathrm{CDCl}_{3}\right)$ $\delta 5.40(\mathrm{~s}, 2 \mathrm{H}), 3.93(\mathrm{~s}, 3 \mathrm{H}), 3.75(\mathrm{~s}, 3 \mathrm{H}), 3.63(\mathrm{~s}, 3 \mathrm{H}) ;{ }^{13} \mathrm{C}-\mathrm{NMR}(150 \mathrm{MHz}$, $\mathrm{CDCl}_{3}$ ) $\delta 158.6,157.6 .155 .9,129.6,99.0,61.9,61.0,58.5,54.6$; HRMS (FAB, $m$-NBA) $[\mathrm{M}+\mathrm{H}]^{+}$calcd for $\mathrm{C}_{9} \mathrm{H}_{13} \mathrm{NO}_{5} \mathrm{I} 341.9838$, found 341.9843 .

\section{3-Iodo-5,6-dimethoxy-2,4-bis(methoxymethoxy)pyridine (4b)}

A solution of $13(29.3 \mathrm{mg}, 85.9 \mu \mathrm{mol})$ in DMF $(1.0 \mathrm{ml})$ was treated with $\mathrm{NaH}$ $(60 \%, 5.0 \mathrm{mg}, 129 \mu \mathrm{mol})$ and $\mathrm{MOMCl}(8 \mu \mathrm{l}, 103 \mu \mathrm{mol})$, and the mixture was stirred at room temperature for $1 \mathrm{~h}$. The resulting solution was partitioned between EtOAc and $\mathrm{H}_{2} \mathrm{O}$. The aqueous layer was extracted with EtOAc, and the organic layers were combined, dried over $\mathrm{Na}_{2} \mathrm{SO}_{4}$, filtered and concentrated in vacuo. The residue was purified by silica gel flash column chromatography (15: 1 hexanes/EtOAc) to afford $\mathbf{4 b}$ (33.4 mg, quant.) as a yellow oil. $\mathrm{mp} 62-$ $64^{\circ} \mathrm{C}$; IR (KBr) 2954, 2838, 2362, 1735, 1562, 1467, 1378, 1214, 1159, 1105, 995, $877 \mathrm{~cm}^{-1}$; ${ }^{1} \mathrm{H}-\mathrm{NMR}\left(270 \mathrm{MHz}, \mathrm{CDCl}_{3}\right) \delta 5.52(\mathrm{~s}, 2 \mathrm{H}), 5.38(\mathrm{~s}, 2 \mathrm{H}), 3.95(\mathrm{~s}$,
$3 \mathrm{H}), 3.76(\mathrm{~s}, 3 \mathrm{H}), 3.63(\mathrm{~s}, 3 \mathrm{H}) 3.55(\mathrm{~s}, 3 \mathrm{H}) ;{ }^{13} \mathrm{C}-\mathrm{NMR}\left(150 \mathrm{MHz}, \mathrm{CDCl}_{3}\right) \delta$ 158.5, 157.0, 155.2, 130.4, 99.0, 92.7, 65.0, 60.9, 58.4, 57.3, 54.1; HRMS (FAB, $m$-NBA) $[\mathrm{M}+\mathrm{H}]^{+}$calcd for $\mathrm{C}_{11} \mathrm{H}_{18} \mathrm{NO}_{6} \mathrm{I} 386.0101$, found 386.0107; Anal. calcd for $\mathrm{C}_{11} \mathrm{H}_{18} \mathrm{NO}_{6} \mathrm{I}$ : C, 4.19; $\mathrm{H}, 34.30$; O, 3.64, found: $\mathrm{C}, 4.10 ; \mathrm{H}, 34.51$; O, 3.67.

\section{(R)-2-Methyl-3-(triisopropylsilyloxy)propyl 4-} methylbenzenesulfonate (15)

A solution of $14(870 \mathrm{mg}, 3.45 \mathrm{mmol})$ in pyridine $(6.9 \mathrm{ml})$ was treated with $p$ - TsCl ( $990 \mathrm{mg}, 5.18 \mathrm{mmol}$ ) and a catalytic amount of DMAP. The mixture was stirred at room temperature for $2 \mathrm{~h}$. The resulting solution was partitioned between EtOAc and $\mathrm{H}_{2} \mathrm{O}$. The aqueous layer was extracted with EtOAc, and the organic layers were combined, dried over $\mathrm{Na}_{2} \mathrm{SO}_{4}$, filtered and concentrated in vacuo. The residue was purified by silica gel flash column chromatography ( $50: 1$ hexanes/EtOAc) to afford $\mathbf{1 5}(1.31 \mathrm{~g}$, quant.) as a colorless oil. [ $\alpha$ ] $27-6.31$ (c 1.0, $\mathrm{CHCl}_{3}$ ); IR (KBr) 2952, 2867, 1600, 1463, 1367, 1182, 1105, 977, 786, 675, $561 \mathrm{~cm}^{-1} ;{ }^{1} \mathrm{H}-\mathrm{NMR}\left(270 \mathrm{MHz}, \mathrm{CDCl}_{3}\right) \delta 7.78(\mathrm{~d}, 2 \mathrm{H}, J=8.3 \mathrm{~Hz}), 7.33(\mathrm{~d}$, $2 \mathrm{H}, J=8.3 \mathrm{~Hz}), 4.06(\mathrm{dd}, 1 \mathrm{H}, J=9.2,6.0 \mathrm{~Hz}), 3.95(\mathrm{dd}, 1 \mathrm{H}, J=9.2,6.0 \mathrm{~Hz}), 3.59$ (dd, $1 \mathrm{H}, J=9.9,5.8 \mathrm{~Hz}), 3.49$ (dd, $1 \mathrm{H}, J=9.9,5.8 \mathrm{~Hz}), 2.43(\mathrm{~s}, 3 \mathrm{H}), 2.00-1.94$ $(\mathrm{m}, 1 \mathrm{H}), 1.05-0.94(\mathrm{~m}, 3 \mathrm{H}), 0.99(\mathrm{bs}, 18 \mathrm{H}), 0.90(\mathrm{~d}, 3 \mathrm{H}, J=6.9 \mathrm{~Hz}) ;{ }^{13} \mathrm{C}-\mathrm{NMR}$ $\left(150 \mathrm{MHz}, \mathrm{CDCl}_{3}\right) \delta 144.5,133.0,129.7,127.8,72.2,64.2,35.9,21.6,17.9,13.2$, 11.8; LRMS (FAB, $m$-NBA) $[\mathrm{M}+\mathrm{H}]^{+} 401,[\mathrm{M}+\mathrm{Na}]^{+} 423$.

\section{(S)-3-Methyl-4-(triisopropylsilyloxy)butanenitrile (16)}

A solution of $15(1.31 \mathrm{~g}, 3.25 \mathrm{mmol})$ in DMSO $(3.3 \mathrm{ml})$ was treated with KCN $(210 \mathrm{mg}, 3.25 \mathrm{mmol})$. After stirring at $100^{\circ} \mathrm{C}$ for $1.5 \mathrm{~h}$, the resulting solution was partitioned between EtOAc and $\mathrm{H}_{2} \mathrm{O}$. The aqueous layer was extracted with EtOAc, and the organic layers were combined, dried over $\mathrm{Na}_{2} \mathrm{SO}_{4}$, filtered and concentrated in vacuo. The residue was purified by silica gel flash column chromatography $(20: 1$ hexanes/EtOAc) to afford $\mathbf{1 6}(850 \mathrm{mg}$, quant.) as a colorless oil. $[\alpha]_{\mathrm{D}}^{27}-18.0\left(c\right.$ 1.0, $\left.\mathrm{CHCl}_{3}\right)$; IR (KBr) 2952, 2867, 2246, 1463, 1108, $883,788,680 \mathrm{~cm}^{-1} ;{ }^{1} \mathrm{H}-\mathrm{NMR}\left(270 \mathrm{MHz}, \mathrm{CDCl}_{3}\right) \delta 3.71(\mathrm{dd}, 1 \mathrm{H}, J=8.4$, $4.3 \mathrm{~Hz}), 3.51(\mathrm{dd}, 1 \mathrm{H}, J=8.4,4.3 \mathrm{~Hz}), 2.53(\mathrm{dd}, 1 \mathrm{H}, J=16.5,6.5 \mathrm{~Hz}), 3.49$ (dd, $1 \mathrm{H}, J=16.5,6.5 \mathrm{~Hz}), 2.10-2.02(\mathrm{~m}, 1 \mathrm{H}), 1.11-1.00(\mathrm{~m}, 3 \mathrm{H}), 1.06$ (bs, $18 \mathrm{H}), 0.98(\mathrm{~d}, 3 \mathrm{H}, J=3.3 \mathrm{~Hz}) ;{ }^{13} \mathrm{C}-\mathrm{NMR}\left(150 \mathrm{MHz}, \mathrm{CDCl}_{3}\right) \delta 118.9,66.4,33.5$, $20.8,17.9,15.8,11.8$; HRMS (FAB, $m-\mathrm{NBA}$ ) $[\mathrm{M}+\mathrm{H}]^{+}$calcd for $\mathrm{C}_{14} \mathrm{H}_{30} \mathrm{NOSi}$ 256.2100, found 256.2096 .

\section{(S)-3-Methyl-4-(triisopropylsilyloxy)butanal (17)}

A solution of $16(850 \mathrm{mg}, 3.33 \mathrm{mmol})$ in $\mathrm{CH}_{2} \mathrm{Cl}_{2}(16 \mathrm{ml})$ was treated with DIBAL $(1.02 \mathrm{M}$ in hexane, $7.5 \mathrm{ml}, 7.65 \mathrm{mmol})$ at $-78^{\circ} \mathrm{C}$. After stirring for $1 \mathrm{~h}$ at $-78^{\circ} \mathrm{C}, 3 \mathrm{~N}$ aqueous $\mathrm{HCl}$ solution was added to the mixture. The aqueous layer was extracted with EtOAc, and the organic layers were combined, dried over $\mathrm{Na}_{2} \mathrm{SO}_{4}$, filtered and concentrated in vacuo. The residue was purified by silica gel flash column chromatography (20:1 hexanes/EtOAc) to afford $17(630 \mathrm{mg}$, $73 \%)$ as a colorless oil. The physical properties of 17 were completely identical to those reported in the literature. ${ }^{11}$

\section{(S,E)-Ethyl 5-methyl-6-(triisopropylsilyloxy)hex-2-enoate (18)}

A solution of $17(630 \mathrm{mg}, 2.44 \mathrm{mmol})$ in benzene $(24 \mathrm{ml})$ was treated with (carbethoxymethylene)triphenylphosphorane $(1.70 \mathrm{~g}, 4.88 \mathrm{mmol})$. After stirring at $50^{\circ} \mathrm{C}$ for $24 \mathrm{~h}$, the resulting solution was partitioned between EtOAc and $\mathrm{H}_{2} \mathrm{O}$. The aqueous layer was extracted with EtOAc, and the organic layers were combined, dried over $\mathrm{Na}_{2} \mathrm{SO}_{4}$, filtered and concentrated in vacuo. The residue was purified by silica gel flash column chromatography (20:1 hexanes/ EtOAc) to afford $18(680 \mathrm{mg}, 85 \%)$ as a colorless oil. $[\alpha]_{\mathrm{D}}^{28}-1.80\left(c 1.0, \mathrm{CHCl}_{3}\right)$; IR (KBr) 2950, 2867, 2350, 2337, 1724, 1654, 1463, 1263, 1174, 1108, 1049, 883, $790,678 \mathrm{~cm}^{-1}$; ${ }^{1} \mathrm{H}-\mathrm{NMR}\left(300 \mathrm{MHz}, \mathrm{CDCl}_{3}\right) \delta 7.02-6.92(\mathrm{~m}, 1 \mathrm{H}), 5.83(\mathrm{~d}, 1 \mathrm{H}$, $J=15.6,1.4 \mathrm{~Hz}), 4.18(\mathrm{q}, 2 \mathrm{H}, J=7.1 \mathrm{~Hz}), 3.56(\mathrm{dd}, 1 \mathrm{H}, J=9.7,6.0 \mathrm{~Hz}), 3.48(\mathrm{dd}$, $1 \mathrm{H}, J=9.7,6.0 \mathrm{~Hz}), 2.47-2.37(\mathrm{~m}, 1 \mathrm{H}), 2.07-1.97(\mathrm{~m}, 1 \mathrm{H}), 1.85-1.78(\mathrm{~m}$, $1 \mathrm{H}), 1.28(\mathrm{t}, 3 \mathrm{H}, J=7.1 \mathrm{~Hz}), 1.09-1.02(\mathrm{~m}, 3 \mathrm{H}), 1.06(\mathrm{bs}, 18 \mathrm{H}), 0.90(\mathrm{~d}, 3 \mathrm{H}$, $J=6.8 \mathrm{~Hz}) ;{ }^{13} \mathrm{C}-\mathrm{NMR}\left(150 \mathrm{MHz}, \mathrm{CDCl}_{3}\right) \delta 166.5,148.0,122.4,67.8,60.0,36.0$, 35.7, 18.0, 16.4, 14.2, 11.9; HRMS (FAB, $m$-NBA) $[\mathrm{M}+\mathrm{H}]^{+}$calcd for $\mathrm{C}_{18} \mathrm{H}_{37} \mathrm{O}_{3} \mathrm{Si} 329.2512$, found 329.2511. 
(S,E)-5-Methyl-6-(triisopropylsilyloxy)hex-2-en-1-ol (19)

A solution of $18(650 \mathrm{mg}, 1.98 \mathrm{mmol})$ in $\mathrm{CH}_{2} \mathrm{Cl}_{2}(20 \mathrm{ml})$ was treated with DIBAL ( $1.02 \mathrm{M}$ in hexane, $4.85 \mathrm{ml}, 4.95 \mathrm{mmol})$ at $-78^{\circ} \mathrm{C}$. After stirring for $1 \mathrm{~h}$ at $0{ }^{\circ} \mathrm{C}, \mathrm{MeOH}$ was added dropwise at $-78^{\circ} \mathrm{C}$ to the resulting solution until the evolution of gas ceased. The mixture was diluted with $\mathrm{CH}_{2} \mathrm{Cl}_{2}$, treated with celite $(1.50 \mathrm{~g})$ and $\mathrm{Na}_{2} \mathrm{SO}_{4} \bullet 10 \mathrm{H}_{2} \mathrm{O}(1.60 \mathrm{~g})$ and then stirred for $12 \mathrm{~h}$ at room temperature. The resulting solution was filtered through a pad of celite, and the filtrate was concentrated in vacuo. The residue was purified by silica gel flash column chromatography (20:1 hexanes/EtOAc) to afford $19(510 \mathrm{mg}, 91 \%)$ as a colorless oil. $[\alpha]_{\mathrm{D}}^{28}-4.27\left(c 1.0, \mathrm{CHCl}_{3}\right)$; IR (KBr) 3334, 2950, 2865, 1463, $1105,1006,883,794,678,595 \mathrm{~cm}^{-1} ;{ }^{1} \mathrm{H}-\mathrm{NMR}\left(270 \mathrm{MHz}, \mathrm{CDCl}_{3}\right) \delta 5.75-5.60$ $(\mathrm{m}, 2 \mathrm{H}), 4.09(\mathrm{~d}, 2 \mathrm{H}, J=4.0 \mathrm{~Hz}), 3.50(\mathrm{~d}, 2 \mathrm{H}, J=3.2 \mathrm{~Hz}), 2.27-2.20(\mathrm{~m}, 1 \mathrm{H})$, $1.91-1.81(\mathrm{~m}, 1 \mathrm{H}), 1.75-1.65(\mathrm{~m}, 1 \mathrm{H}), 1.12-1.02(\mathrm{~m}, 3 \mathrm{H}), 1.06(\mathrm{bs}, 18 \mathrm{H})$, $0.88(\mathrm{~d}, 3 \mathrm{H}, J=6.6 \mathrm{~Hz}) ;{ }^{13} \mathrm{C}-\mathrm{NMR}\left(150 \mathrm{MHz}, \mathrm{CDCl}_{3}\right) \delta 131.7,130.3,68.0$, $63.7,36.1,35.9,18.0,16.4,12.0$; HRMS (FAB, $m$-NBA) $[\mathrm{M}+\mathrm{H}]^{+}$calcd for $\mathrm{C}_{16} \mathrm{H}_{35} \mathrm{O}_{3} \mathrm{Si}$ 287.2403, found 287.2408.

\section{$\{(2 R, 3 R)-3-[(S)-2-M e t h y l-3-($ triisopropylsilyloxy)propyl] oxiran-2-yl $\}$ methanol $(20)$}

A mixture of $\mathrm{Ti}(\mathrm{O} i \mathrm{Pr})_{4}(3.2 \mathrm{ml}, 10.8 \mathrm{mmol})$ and $4 \AA \mathrm{MS}(1.24 \mathrm{~g})$ in $\mathrm{CH}_{2} \mathrm{Cl}_{2}$ $(50 \mathrm{ml})$ was treated with $(-)$-DET $(1.9 \mathrm{ml}, 10.8 \mathrm{mmol})$, and the solution was vigorously stirred at $-5^{\circ} \mathrm{C}$ for $0.5 \mathrm{~h}$. TBHP $(5.0-6.0 \mathrm{M}$ in decane, $4.4 \mathrm{ml}$, $21.6 \mathrm{mmol}$ ) was slowly added to the above mixture, and the solution was stirred at $-20^{\circ} \mathrm{C}$ for $20 \mathrm{~min}$. A solution of $19(3.10 \mathrm{~g}, 10.8 \mathrm{mmol})$ in $\mathrm{CH}_{2} \mathrm{Cl}_{2}$ $(58 \mathrm{ml})$ was added to the above mixture, and the solution was stirred at $-20^{\circ} \mathrm{C}$ for $10.5 \mathrm{~h}$. After $\mathrm{Me}_{2} \mathrm{~S}(1.19 \mathrm{ml}, 16.2 \mathrm{mmol})$ was added, the mixture was further stirred at $-20^{\circ} \mathrm{C}$ for $1 \mathrm{~h}$. The resulting mixture was diluted with $\mathrm{Et}_{2} \mathrm{O}$, treated with celite $(6.50 \mathrm{~g})$ and $\mathrm{Na}_{2} \mathrm{SO}_{4} \cdot 10 \mathrm{H}_{2} \mathrm{O}(6.50 \mathrm{~g})$, and then stirred for $2 \mathrm{~h}$ at room temperature. The resulting suspension was filtered through a pad of celite, and the filtrate was concentrated in vacuo. The residue was purified by silica gel flash column chromatography (5:1 hexanes/EtOAc) to afford 20 (3.27 g, quant.) as a colorless oil. $[\alpha]_{\mathrm{D}}^{28}+16.1\left(c 1.0, \mathrm{CHCl}_{3}\right)$; IR $(\mathrm{KBr}) 3432$, 2944, 2865, 1463, 1382, 1103, 887, 792, 678, $653 \mathrm{~cm}^{-1}$; ${ }^{1} \mathrm{H}-\mathrm{NMR}(270 \mathrm{MHz}$, $\left.\mathrm{CDCl}_{3}\right) \delta 3.56(\mathrm{~m}, 4 \mathrm{H}), 3.09-3.02(\mathrm{~m}, 1 \mathrm{H}), 2.90-2.88(\mathrm{~m}, 1 \mathrm{H}), 1.85-1.75(\mathrm{~m}$, $3 \mathrm{H}), 1.11-1.02(\mathrm{~m}, 3 \mathrm{H}), 1.06(\mathrm{bs}, 18 \mathrm{H}), 0.99(\mathrm{~d}, 3 \mathrm{H}, J=6.6 \mathrm{~Hz}) ;{ }^{13} \mathrm{C}-\mathrm{NMR}$ $\left(150 \mathrm{MHz}, \mathrm{CDCl}_{3}\right) \delta 68.0,61.7,58.4,55.1,35.4,34.5,18.0,17.0,11.9 ;$ HRMS (ESI) $[\mathrm{M}+\mathrm{Na}]^{+}$calcd for $\mathrm{C}_{16} \mathrm{H}_{34} \mathrm{O}_{3} \mathrm{SiNa} 325.2175$, found 325.2212 .

Triisopropyl $\{[(S)$-2-methyl-3-(2R,3R)-3-(triphenylmethyloxymethyl) oxiran-2-yl]propoxy\}silane (21)

A solution of $20(496 \mathrm{mg}, 1.46 \mathrm{mmol})$ in $\mathrm{CH}_{2} \mathrm{Cl}_{2}(16 \mathrm{ml})$ was treated with $\mathrm{TrCl}$ (914 $\mathrm{mg}, 3.28 \mathrm{mmol})$ and $\mathrm{Et}_{3} \mathrm{~N}(680 \mu \mathrm{l}, 4.92 \mathrm{mmol})$, and the mixture was stirred at room temperature for $8.5 \mathrm{~h}$. The resulting solution was partitioned between $\mathrm{CH}_{2} \mathrm{Cl}_{2}$ and $\mathrm{H}_{2} \mathrm{O}$. The aqueous layer was extracted with $\mathrm{CH}_{2} \mathrm{Cl}_{2}$, and the organic layers were combined, dried over $\mathrm{Na}_{2} \mathrm{SO}_{4}$, filtered and concentrated in vacuo. The residue was purified by silica gel flash column chromatography (150:1 hexanes/EtOAc) to afford $21(869 \mathrm{mg}, 97 \%)$ as a colorless oil. $[\alpha]_{\mathrm{D}}^{28}$ +4.76 (c 1.0, $\mathrm{CHCl}_{3}$ ); IR (KBr) 2942, 2865, 1596, 1490, 1448, 1091, 1070, 883, $702 \mathrm{~cm}^{-1} ;{ }^{1} \mathrm{H}-\mathrm{NMR}\left(300 \mathrm{MHz}, \mathrm{CDCl}_{3}\right) \delta 7.48-7.12(\mathrm{~m}, 15 \mathrm{H}), 3.57(\mathrm{dd}, 1 \mathrm{H}$, $J=9.6,5.7 \mathrm{~Hz}), 3.51(\mathrm{dd}, 1 \mathrm{H}, J=9.6,6.0 \mathrm{~Hz}), 3.26(\mathrm{dd}, 1 \mathrm{H}, J=10.6,3.2 \mathrm{~Hz}), 3.12$ (dd, $1 \mathrm{H}, J=10.6,5.4 \mathrm{~Hz}) 2.92-2.84(\mathrm{~m}, 2 \mathrm{H}), 1.88-1.78(\mathrm{~m}, 1 \mathrm{H}), 1.77-1.69$ (m, $1 \mathrm{H}), 1.41-1.31(\mathrm{~m}, 1 \mathrm{H}), 1.10-0.95(\mathrm{~m}, 3 \mathrm{H}), 1.03$ (bs, $18 \mathrm{H}), 0.99$ (d, 3H, $J=6.7 \mathrm{~Hz}) ;{ }^{13} \mathrm{C}-\mathrm{NMR}\left(150 \mathrm{MHz}, \mathrm{CDCl}_{3}\right) \delta 143.8,128.6,127.8,127.0,86.6,68.0$, $64.6,57.1,55.4,35.6,34.5,18.0,17.1,11.9$; HRMS (FAB, $m$-NBA) $[\mathrm{M}+\mathrm{Na}]^{+}$ calcd for $\mathrm{C}_{35} \mathrm{H}_{48} \mathrm{O}_{3} \mathrm{SiNa}$ 567.3271, found 567.3248.

\section{(2S,3S,5S)-3,5-Dimethyl-6-(triisopropylsilyloxy)-1-(trityloxy)}

hexan-2-ol (22)

A mixture of $\mathrm{CuI}(1.57 \mathrm{~g}, 8.25 \mathrm{mmol})$ in $\mathrm{CH}_{2} \mathrm{Cl}_{2}(8.0 \mathrm{ml})$ was treated with $\mathrm{MeLi}$ $\left(1.04 \mathrm{M}\right.$ in $\left.\mathrm{Et}_{2} \mathrm{O}, 15.8 \mathrm{ml}, 16.5 \mathrm{mmol}\right)$, and the solution was stirred at $-78^{\circ} \mathrm{C}$ for $5 \mathrm{~min} . \mathrm{BF}_{3} \cdot \mathrm{OEt}_{2}(314 \mu \mathrm{l}, 2.48 \mathrm{mmol})$ was added to the above mixture, and the solution was stirred at $-78^{\circ} \mathrm{C}$ for $5 \mathrm{~min}$. A solution of 21 ( $900 \mathrm{mg}, 1.65 \mathrm{mmol}$ ) in $\mathrm{CH}_{2} \mathrm{Cl}_{2}(8.5 \mathrm{ml})$ was added to the above mixture, and the solution was stirred at $-78^{\circ} \mathrm{C}$ for $2 \mathrm{~h}$. The reaction mixture was warmed to room temperature and treated with saturated aqueous $\mathrm{NH}_{4} \mathrm{Cl}$. The resulting solution was partitioned between EtOAc and $\mathrm{H}_{2} \mathrm{O}$. The aqueous layer was extracted with
EtOAc, and the organic layers were combined, dried over $\mathrm{Na}_{2} \mathrm{SO}_{4}$, filtered and concentrated in vacuo. The residue was purified by silica gel flash column chromatography (50:1 hexanes/EtOAc) to afford $22(720 \mathrm{mg}, 97 \%)$ as a colorless oil. $[\alpha]_{\mathrm{D}}^{26}-4.09\left(\right.$ c $\left.1.0, \mathrm{CHCl}_{3}\right)$; IR $(\mathrm{KBr}) 3478,2950,2865,1712$, $1596,1455,1378,1097,1074,887,773,698 \mathrm{~cm}^{-1}$; ${ }^{1} \mathrm{H}-\mathrm{NMR}\left(270 \mathrm{MHz}, \mathrm{CDCl}_{3}\right)$ $\delta 7.47-7.20(\mathrm{~m}, 15 \mathrm{H}), 3.58-3.53(\mathrm{~m}, 1 \mathrm{H}), 3.43(\mathrm{~d}, 2 \mathrm{H}, J=6.3 \mathrm{~Hz}), 3.26(\mathrm{dd}$, $1 \mathrm{H}, J=9.4,3.2 \mathrm{~Hz}), 3.08(\mathrm{dd}, 1 \mathrm{H}, J=9.4,7.9 \mathrm{~Hz}), 2.38(\mathrm{~d}, 1 \mathrm{H}, J=3.3 \mathrm{~Hz})$, $1.72-1.56(\mathrm{~m}, 2 \mathrm{H}), 1.26-1.13(\mathrm{~m}, 2 \mathrm{H}), 1.07-1.01(\mathrm{~m}, 3 \mathrm{H}), 1.04(\mathrm{bs}, 18 \mathrm{H})$, $0.81(\mathrm{~d}, 3 \mathrm{H}, J=6.6 \mathrm{~Hz}), 0.72(\mathrm{~d}, 3 \mathrm{H}, J=6.8 \mathrm{~Hz}) ;{ }^{13} \mathrm{C}-\mathrm{NMR}\left(150 \mathrm{MHz}, \mathrm{CDCl}_{3}\right) \delta$ $143.9,128.6,127.8,127.0,86.7,75.2,69.4,65.6,35.5,33.4,33.3,18.0,16.1,15.0$, 12.0; HRMS (FAB, $m$-NBA) $[\mathrm{M}+\mathrm{Na}]^{+}$calcd for $\mathrm{C}_{36} \mathrm{H}_{52} \mathrm{O}_{3} \mathrm{SiNa} 583.3583$, found 583.3607.

(2S,3S,5S)-3,5-Dimethyl-6-(triisopropylsilyloxy)hexan-1,2-diol (23) To a mixture of $\mathrm{Li}(57.7 \mathrm{mg}, 8.89 \mathrm{mmol})$ in liquid ammonia $(9.0 \mathrm{ml}, 0.1 \mathrm{M})$ was added a solution of $22(498 \mathrm{mg}, 0.890 \mathrm{mmol})$ in THF $(5.0 \mathrm{ml})$ and $t \mathrm{BuOH}$ $(0.21 \mathrm{ml}, 2.22 \mathrm{mmol})$ at $-78{ }^{\circ} \mathrm{C}$, and the resulting solution was stirred at $-78^{\circ} \mathrm{C}$ for $30 \mathrm{~min}$. $\mathrm{MeOH}$ was added at $-78^{\circ} \mathrm{C}$ until the color of the solution changed, and after complete volatilization of ammonia, the resulting solution was partitioned between EtOAc and $\mathrm{H}_{2} \mathrm{O}$. The aqueous layer was extracted with EtOAc, and the organic layers were combined, dried over $\mathrm{Na}_{2} \mathrm{SO}_{4}$, filtered and concentrated in vacuo. The residue was purified by silica gel flash column chromatography (5:1 hexanes/EtOAc) to afford $23(241 \mathrm{mg}, 85 \%)$ as a colorless oil. [ $\alpha]_{\mathrm{D}}^{27}-17.8\left(c 1.0, \mathrm{CHCl}_{3}\right)$; IR ( $\left.\mathrm{KBr}\right) 3419,2948,2867,1625,1461,1382$, $1105,1068,881,790,678 \mathrm{~cm}^{-1}$; ${ }^{1} \mathrm{H}-\mathrm{NMR}\left(300 \mathrm{MHz}, \mathrm{CDCl}_{3}\right) \delta 3.75-3.68$ $(\mathrm{m}, 1 \mathrm{H}), 3.54-3.44(\mathrm{~m}, 4 \mathrm{H}), 1.76-1.65(\mathrm{~m}, 2 \mathrm{H}), 1.42-1.23(\mathrm{~m}, 2 \mathrm{H})$, $1.13-1.02(\mathrm{~m}, 3 \mathrm{H}), 1.07$ (bs, $18 \mathrm{H}), 0.88(\mathrm{~d}, 3 \mathrm{H}, J=6.6 \mathrm{~Hz}), 0.85(\mathrm{~d}, 3 \mathrm{H}$, $J=6.6 \mathrm{~Hz}) ;{ }^{13} \mathrm{C}-\mathrm{NMR}\left(150 \mathrm{MHz}, \mathrm{CDCl}_{3}\right) \delta 78.8,71.9,67.9,36.3,34.7,32.4$, $17.9,17.3,15.1,12.1$; HRMS (FAB, $m$-NBA) $[\mathrm{M}+\mathrm{Na}]^{+}$calcd for $\mathrm{C}_{17} \mathrm{H}_{38} \mathrm{O}_{3} \mathrm{SiNa}$ 341.2488 , found 341.2490

\section{(2S,4S,5R)-5,6-Dichloro-2,4-dimethylhexan-1-ol (24)}

A solution of $23(211 \mathrm{mg}, 0.660 \mathrm{mmol})$ in THF $(3.3 \mathrm{ml})$ was treated with NCS (266 mg, $1.99 \mathrm{mmol})$ and $\mathrm{PPh}_{3}(552 \mathrm{mg}, 1.99 \mathrm{mmol}$ ), and the mixture was stirred at $60^{\circ} \mathrm{C}$ for $3 \mathrm{~h}$. The resulting solution was partitioned between $\mathrm{CH}_{2} \mathrm{Cl}_{2}$ and $\mathrm{H}_{2} \mathrm{O}$. The aqueous layer was extracted with $\mathrm{CH}_{2} \mathrm{Cl}_{2}$. The organic layer was combined, dried over $\mathrm{Na}_{2} \mathrm{SO}_{4}$, filtered and concentrated in vacuo. The residue was semi-purified by flash silica gel column chromatography ( $5: 1$ hexanes/ EtOAc) to afford the crude dichloride as a colorless oil. A solution of the crude dichloride in THF $(6.6 \mathrm{ml})$ was treated with TBAF $(1.0 \mathrm{M}$ THF, $1.32 \mathrm{ml}$, $1.32 \mathrm{mmol})$, and the reaction mixture was stirred at room temperature for $1 \mathrm{~h}$ and quenched with saturated aqueous $\mathrm{NH}_{4} \mathrm{Cl}$. The resulting solution was partitioned between EtOAc and $\mathrm{H}_{2} \mathrm{O}$. The aqueous layer was extracted with EtOAc, and the organic layers were combined, dried over $\mathrm{Na}_{2} \mathrm{SO}_{4}$, filtered and concentrated in vacuo. The residue was purified by silica gel flash column chromatography (5:1 hexanes/EtOAc) to afford $\mathbf{2 4}(86.0 \mathrm{mg}, 65 \%$ for 2 steps) as a colorless oil. $[\alpha]_{\mathrm{D}}^{27}-11.3\left(c 1.0, \mathrm{CHCl}_{3}\right)$; IR $(\mathrm{KBr}) 3365,2964,2925,1457$, $1380,1037,738,686 \mathrm{~cm}^{-1} ;{ }^{1} \mathrm{H}-\mathrm{NMR}\left(270 \mathrm{MHz}, \mathrm{CDCl}_{3}\right) \delta 4.12-4.06(\mathrm{~m}, 1 \mathrm{H})$, $3.81-3.66(\mathrm{~m}, 2 \mathrm{H}), 3.56-3.41(\mathrm{~m}, 2 \mathrm{H}), 2.32-2.25(\mathrm{~m}, 1 \mathrm{H}), 1.78-1.69$ $(\mathrm{m}, 1 \mathrm{H}), 1.55-1.45(\mathrm{~m}, 2 \mathrm{H}), 0.94(\mathrm{~d}, 3 \mathrm{H}, J=6.6 \mathrm{~Hz}), 0.93(\mathrm{~d}, 3 \mathrm{H}, J=6.6 \mathrm{~Hz})$; ${ }^{13} \mathrm{C}-\mathrm{NMR}\left(150 \mathrm{MHz}, \mathrm{CDCl}_{3}\right) \delta 73.1,61.6,46.0,35.0,33.8,31.8,18.0,17.6,15.4$, 12.0; HRMS (FAB, $m$-NBA) $[\mathrm{M}+\mathrm{H}]^{+}$calcd for $\mathrm{C}_{8} \mathrm{H}_{17} \mathrm{Cl}_{2} \mathrm{O}$ 199.0656, found 199.0647.

\section{(2S,4S,5R)-5,6-Dichloro-2,4-dimethylhexanal (5)}

A solution of $24(54.0 \mathrm{mg}, 0.270 \mathrm{mmol})$ in $\mathrm{CH}_{2} \mathrm{Cl}_{2}(2.7 \mathrm{ml})$ was treated with TEMPO $(4.3 \mathrm{mg}, 27.1 \mu \mathrm{mol})$ and $\mathrm{PhI}(\mathrm{OAc})_{2}(131 \mathrm{mg}, 0.410 \mathrm{mmol})$. The reaction mixture was then stirred at room temperature for $2.5 \mathrm{~h}$ and quenched with saturated aqueous $\mathrm{Na}_{2} \mathrm{~S}_{2} \mathrm{O}_{3}$. The resulting solution was partitioned between $\mathrm{CH}_{2} \mathrm{Cl}_{2}$ and $\mathrm{H}_{2} \mathrm{O}$. The aqueous layer was extracted with $\mathrm{CH}_{2} \mathrm{Cl}_{2}$, and the organic layers were combined, dried over $\mathrm{Na}_{2} \mathrm{SO}_{4}$, filtered and concentrated in vacuo. The residue was purified by silica gel flash column chromatography $(20: 1$ hexanes/EtOAc) to afford $\mathbf{5}(43.0 \mathrm{mg}, 81 \%)$ as a colorless oil. $[\alpha]_{\mathrm{D}}^{27}+1.13\left(\right.$ c $\left.1.0, \mathrm{CHCl}_{3}\right)$; IR ( $\left.\mathrm{KBr}\right) 2971,2715,1725,1457$, $1382,1257,925,815,740,688 \mathrm{~cm}^{-1} ;{ }^{1} \mathrm{H}-\mathrm{NMR}\left(300 \mathrm{MHz}, \mathrm{CDCl}_{3}\right) \delta 9.64(\mathrm{~d}$, $1 \mathrm{H}, J=8.6 \mathrm{~Hz}), 4.13-4.07(\mathrm{~m}, 1 \mathrm{H}), 3.78(\mathrm{dd}, 1 \mathrm{H}, J=11.3,5.7 \mathrm{~Hz}), 3.70(\mathrm{dd}, 1 \mathrm{H}$, 
$J=11.3,8.8 \mathrm{~Hz}), 2.48-2.39(\mathrm{dq}, 1 \mathrm{H}, J=7.0,1.8 \mathrm{~Hz}), 2.33-2.25(\mathrm{~m}, 1 \mathrm{H})$, $1.89-1.79(\mathrm{~m}, 1 \mathrm{H}), 1.48-1.38(\mathrm{~m}, 1 \mathrm{H}), 1.14(\mathrm{~d}, 3 \mathrm{H}, J=7.0 \mathrm{~Hz}), 0.95(\mathrm{~d}, 3 \mathrm{H}$, $J=6.6 \mathrm{~Hz}$ ); HRMS (FAB, $m$-NBA) $[\mathrm{M}+\mathrm{Na}]^{+}$calcd for $\mathrm{C}_{8} \mathrm{H}_{14} \mathrm{Cl}_{2} \mathrm{O} 196.0422$, found 199.0431 .

\section{(2S,4S,5R)-5,6-Dichloro-1-(5,6-dimethoxy-2,4-bis(methoxymethoxy) pyridin-3-yl)-2,4-dimethylhexan-1-ol (25)}

To a solution of $n$-BuLi $(1.59 \mathrm{M}$ in hexane, $672 \mu \mathrm{l}, 1.07 \mathrm{mmol})$ in THF $(3.6 \mathrm{ml})$ was added a solution of $\mathbf{4 b}(138 \mathrm{mg}, 359 \mu \mathrm{mol})$ in THF $(1.8 \mathrm{ml})$ at $-78^{\circ} \mathrm{C}$. A solution of $5(58.0 \mathrm{mg}, 299 \mu \mathrm{mol})$ in THF $(1.8 \mathrm{ml})$ was then added and the mixture was stirred for $15 \mathrm{~min}$ at $-78^{\circ} \mathrm{C}$. $\mathrm{MeOH}$ was added, and the resulting solution was partitioned between EtOAc and $\mathrm{H}_{2} \mathrm{O}$. The aqueous layer was extracted with EtOAc, and the organic layers were combined, dried over $\mathrm{Na}_{2} \mathrm{SO}_{4}$, filtered and concentrated in vacuo. The residue was purified by silica gel flash column chromatography (3:1 hexanes/EtOAc) to afford a diastereomixture of $\mathbf{2 5}(101 \mathrm{mg}, 83 \%)$ as a colorless oil. [ $\alpha]_{\mathrm{D}}^{20}-11.8\left(c 1.0, \mathrm{CHCl}_{3}\right)$; IR (KBr) 3561, 2962, 1590,1469, 1392, 1160, 1116, 1060, 1025, $904 \mathrm{~cm}^{-1} ;{ }^{1} \mathrm{H}-$ $\operatorname{NMR}\left(300 \mathrm{MHz}, \mathrm{CDCl}_{3}\right) \delta 5.60-5.47(\mathrm{~m}, 2 \mathrm{H}), 5.38-5.27(\mathrm{~m}, 2 \mathrm{H}), 4.16-4.05$ $(\mathrm{m}, 1 \mathrm{H}), 3.93(\mathrm{~s}, 3 \mathrm{H}), 3.83-3.65(\mathrm{~m}, 2 \mathrm{H}), 3.75(\mathrm{~s}, 3 \mathrm{H}), 3.74(\mathrm{~s}, 3 \mathrm{H}), 3.58-3.50$ (m, $1 \mathrm{H}), 3.57(\mathrm{~s}, 3 \mathrm{H}), 3.56(\mathrm{~s}, 3 \mathrm{H}), 3.52(\mathrm{~s}, 6 \mathrm{H}), 2.37-2.25(\mathrm{~m}, 1 \mathrm{H}), 2.21-2.10$ $(\mathrm{m}, 1 \mathrm{H}), 2.08-2.00(\mathrm{~m}, 1 \mathrm{H}), 1.64-1.51(\mathrm{~m}, 1 \mathrm{H}), 1.07(\mathrm{~d}, 3 \mathrm{H}, J=6.6 \mathrm{~Hz}), 0.96$ $(\mathrm{d}, 3 \mathrm{H}, J=6.5 \mathrm{~Hz}), 0.82(\mathrm{~d}, 3 \mathrm{H}, J=6.9 \mathrm{~Hz}), 0.73(\mathrm{~d}, 3 \mathrm{H}, J=6.7 \mathrm{~Hz}) ;{ }^{13} \mathrm{C}-\mathrm{NMR}$ $\left(150 \mathrm{MHz}, \mathrm{CDCl}_{3}\right) \delta 157.3,157.2,155.2 \times 2,153.2,153.1,130.0 \times 2,110.0 \times 2$, $99.4 \times 2,92.1 \times 2,72.4,71.9,67.7,66.9,60.8 \times 2,58.1 \times 2,57.7 \times 2,53.9,53.8,46.5$, $45.4,38.7,38.3,36.7,36.6,33.2,32.6,16.6,16.2,13.0,12.6$; HRMS (FAB, $m$-NBA) $[\mathrm{M}+\mathrm{Na}]^{+}$calcd for $\mathrm{C}_{19} \mathrm{H}_{31} \mathrm{Cl}_{2} \mathrm{NO}_{7} 478.1373$, found 478.1378 .

\section{(2S,4S,5R)-5,6-Dichloro-1-(5,6-dimethoxy-2,4-bis(methoxymethoxy)} pyridin-3-yl)-2,4-dimethylhexan-1-one (26)

A solution of $25(93.3 \mathrm{mg}, 205 \mu \mathrm{mol})$ in $\mathrm{CH}_{2} \mathrm{Cl}_{2}(2.0 \mathrm{ml})$ was treated with Dess-Martin periodinane $(130 \mathrm{mg}, 307 \mu \mathrm{mol})$. The mixture was then stirred at room temperature for $15 \mathrm{~min}$ and quenched with saturated aqueous $\mathrm{Na}_{2} \mathrm{~S}_{2} \mathrm{O}_{3}$ and saturated aqueous $\mathrm{NaHCO}_{3}$. The resulting solution was partitioned between $\mathrm{CH}_{2} \mathrm{Cl}_{2}$ and $\mathrm{H}_{2} \mathrm{O}$. The aqueous layer was extracted with $\mathrm{CH}_{2} \mathrm{Cl}_{2}$, and the organic layers were combined, dried over $\mathrm{Na}_{2} \mathrm{SO}_{4}$, filtered and concentrated in vacuo. The residue was purified by silica gel flash column chromatography (10:1 hexanes/EtOAc) to afford $26(79.5 \mathrm{mg}, 86 \%)$ as a colorless oil. $[\alpha]_{\mathrm{D}}^{27}-2.91$ (c 1.0, $\mathrm{CHCl}_{3}$ ); IR ( $\left.\mathrm{KBr}\right) 2971,2715,1725,1457$, $1382,1257,925,815,740,688 \mathrm{~cm}^{-1}$; ${ }^{1} \mathrm{H}-\mathrm{NMR}\left(300 \mathrm{MHz}, \mathrm{CDCl}_{3}\right) \delta 5.50(\mathrm{~s}$, $2 \mathrm{H}), 5.30(\mathrm{~s}, 2 \mathrm{H}), 4.19(\mathrm{ddd}, 1 \mathrm{H}, J=7.6,6.3,2.9 \mathrm{~Hz}), 3.97(\mathrm{~s}, 3 \mathrm{H}), 3.77(\mathrm{~s}, 3 \mathrm{H})$, $3.78-3.63(\mathrm{~m}, 2 \mathrm{H}), 3.49(\mathrm{~s}, 6 \mathrm{H}), 3.24-3.12(\mathrm{~m}, 1 \mathrm{H}), 2.37-2.26(\mathrm{~m}, 1 \mathrm{H})$, $1.94-1.84(\mathrm{~m}, 1 \mathrm{H}), 1.51-1.46(\mathrm{~m}, 1 \mathrm{H}), 1.17(\mathrm{~d}, 3 \mathrm{H}, J=7.0 \mathrm{~Hz}), 0.93(\mathrm{~d}, 3 \mathrm{H}$, $J=6.6 \mathrm{~Hz}) ;{ }^{13} \mathrm{C}-\mathrm{NMR}\left(150 \mathrm{MHz}, \mathrm{CDCl}_{3}\right) \delta 204.8,157.3,156.3,152.9,130.1$, 110.7, 99.1, 92.0, 66.2, 60.9, 57.9, 57.6, 54.2, 46.5, 44.2, 37.3, 32.7, 16.8, 13.0; HRMS (FAB, $m$-NBA) $[\mathrm{M}+\mathrm{Na}]^{+}$calcd for $\mathrm{C}_{19} \mathrm{H}_{29} \mathrm{Cl}_{2} \mathrm{~N} \mathrm{Na} \mathrm{O}$ 476.1219, found 476.1210 .

\section{Atpenin A5 (3)}

A solution of $26(76.7 \mathrm{mg}, 169 \mu \mathrm{mol})$ in $\mathrm{CH}_{2} \mathrm{Cl}_{2}(1.7 \mathrm{ml})$ was treated with TFA $(1.7 \mathrm{ml})$ at $0{ }^{\circ} \mathrm{C}$, and the mixture was stirred at $0{ }^{\circ} \mathrm{C}$ for $0.5 \mathrm{~h}$. The reaction mixture was concentrated in vacuo. The residue was purified by silica gel flash column chromatography (5:1 hexanes/EtOAc) to afford atpenin A5 (3) (57.4 $\mathrm{mg}, 93 \%)$ as a white solid.

Synthetic atpenin A5 (3). $\mathrm{mp} 83-85^{\circ} \mathrm{C} ;[\alpha]_{\mathrm{D}}^{25}-0.82$ (c 1.0, EtOH); IR (KBr) $1648,1602,1454,1324,1199,1160,993 \mathrm{~cm}^{-1} ;{ }^{1} \mathrm{H}-\mathrm{NMR}\left(400 \mathrm{MHz}, \mathrm{CDCl}_{3}\right) \delta$ $4.13(\mathrm{~s}, 3 \mathrm{H}), 4.14-4.10(\mathrm{~m}, 2 \mathrm{H}), 3.82(\mathrm{~s}, 3 \mathrm{H}), 3.74(\mathrm{dd}, 1 \mathrm{H}, J=11.1,6.1 \mathrm{~Hz})$, 3.65 (dd, $1 \mathrm{H}, J=11.3,8.5 \mathrm{~Hz}$ ), $2.21(\mathrm{dq}, 1 \mathrm{H}, J=7.1,2.4 \mathrm{~Hz}), 1.91$ (ddd, $1 \mathrm{H}$, $J=14.2,6.9,6.9 \mathrm{~Hz}), 1.55-1.47(\mathrm{~m}, 1 \mathrm{H}), 1.18(\mathrm{~d}, 3 \mathrm{H}, J=6.7 \mathrm{~Hz}), 0.95(\mathrm{~d}, 3 \mathrm{H}$, $J=6.6 \mathrm{~Hz}) ;{ }^{13} \mathrm{C}-\mathrm{NMR}\left(150 \mathrm{MHz}, \mathrm{CDCl}_{3}\right) \delta 210.0,172.8,162.2,155.6,121.2$, $101.1,65.7,61.8,58.6,46.1,39.6,37.7,32.8,18.3,13.2$; HRMS (FAB, $m$-NBA) $[\mathrm{M}+\mathrm{H}]^{+}$calcd for $\mathrm{C}_{15} \mathrm{H}_{22} \mathrm{NO}_{5} \mathrm{Cl}_{2} 366.0875$, found 366.0876; Anal. calcd for $\mathrm{C}_{15} \mathrm{H}_{22} \mathrm{NO}_{5} \mathrm{Cl}_{2}$ : C, 5.78; H, 49.19; O, 3.82, found: $\mathrm{C}, 5.64 ; \mathrm{H}, 49.37$; O, 3.92; $\mathrm{UV} \lambda_{\max }^{\mathrm{EtOH}} \mathrm{nm}\left(\varepsilon\left(\mathrm{cm}^{2} \mathrm{mmol}^{-1}\right)\right) 239$ (3160), 277 (2220), 333 (1450).

Revised data of natural atpenin A5 (3). ${ }^{1} \mathrm{H}-\mathrm{NMR}\left(400 \mathrm{MHz}, \mathrm{CDCl}_{3}\right) \delta 4.13(\mathrm{~s}$, $\mathrm{H}), 4.14-4.10(\mathrm{~m}, 2 \mathrm{H}), 3.82(\mathrm{~s}, 3 \mathrm{H}), 3.73(\mathrm{dd}, 1 \mathrm{H}, J=11.2,5.9 \mathrm{~Hz}), 3.65(\mathrm{dd}$, $1 \mathrm{H}, J=11.3,8.9 \mathrm{~Hz}), 2.20(\mathrm{dq}, 1 \mathrm{H}, J=7.0,2.7 \mathrm{~Hz}), 1.91$ (ddd, $1 \mathrm{H}, J=14.3,7.0$, $7.0 \mathrm{~Hz}), 1.55-1.47(\mathrm{~m}, 1 \mathrm{H}), 1.18(\mathrm{~d}, 3 \mathrm{H}, J=6.7 \mathrm{~Hz}), 0.95(\mathrm{~d}, 3 \mathrm{H}, J=6.5 \mathrm{~Hz})$.

\section{ACKNOWLEDGEMENTS}

We thank Ms N Sato, Ms A Nakagawa and Dr K Nagai (Kitasato University) for kindly measuring NMR and MS spectra and Elemental analytical data. We also acknowledge Dr T Izuhara for helpful discussions. MO acknowledges a Kitasato University research grant for young researchers.

1 Ōmura, S. et al. Atpenins, new antifungal antibiotics produced by Penicillium sp. Production, isolation, physico-chemical and biological properties. J. Antibiot. 41, 1769-1773 (1988).

2 Oshino, K., Kumagai, H., Tomoda, H. \& Ōmura, S. Mechanism of action of atpenin B on Raji cells. J. Antibiot. 43, 1064-1068 (1990).

3 Kumagai, H. et al. The structures of atpenins A4, A5 and B, new antifungal antibiotics produced by Penicillium sp. J. Antibiot. 43, 1553-1558 (1990).

4 Trécourt, F., Mallet, M., Mongin, O. \& Quéguiner, G. Total synthesis of ( \pm )-Atpenin B. An original 'Clockwise' functionalization of 2-chloropyridine. J. Org. Chem. 59, 61736178 (1994).

5 Miyadera, $\mathrm{H}$. et al. Atpenins, potent and specific inhibitors of mitochondrial complex II (succinate-ubiquinone oxidoreductase). Proc. Natl Acad. Sci. USA 100, 473-477 (2003).

6 Horsefield, R. et al. Structural and computational analysis of the quinone-binding site of complex II (succinate-ubiquinone oxidoreductase). J. Biol. Chem. 281, 7309-7316 (2006).

7 Schnürch, M., Spina, M., Khan, A. F., Milhovilovic, M. D. \& Stanetty, P. Halogen dance reactions-A review. Chem. Soc. Rev. 36, 1046-1057 (2007) Recent review.

8 Katsuki, T. \& Sharpless, K. B. The first practical method for asymmetric epoxidation. J. Am. Chem. Soc. 102, 5974-5976 (1980).

9 Kay, A. J. et al. Simple zwitterionic merocyanines as potential NLO chromophores. J. Mater. Chem. 11, 2271-2281 (2001).

10 Komatsu, K., Tanino, K. \& Miyashita, M. Stereoselective total synthesis of the ionophore antibiotic zincophorin. Angew. Chem. Int. Ed. 43, 4341-4345 (2004).

11 Ouellet, S. G., Tuttle, J. B. \& MacMillan, D. W. C. Enantioselective organocatalytic hydride reduction. J. Am. Chem. Soc. 127, 32-33 (2005).

12 Brondel, N., Renoux, B. \& Gesson, J. P. New strategy for the synthesis of phosphatase inhibitors TMC-69-6H and analogs. Tetrahedron Lett. 47, 9305-9308 (2006).

13 Schiavi, B. et al. Synthesis of 5-deazathiogirollines: analogs of a natural antitumor agent. Tetrahedron 58, 4201-4215 (2002). 